\title{
Policing Guns and Youth Violence
}

J effrey Fagan

\section{SUMMARY}

To combat the epidemic of youth gun violence in the 1980s and 1990s, law enforcement agencies across the U nited States adopted a variety of innovative strategies. This article presents case studies of eight cities' efforts to police gun crime. Some cities emphasized police-citizen partnerships to address youth violence, whereas others focused on aggressive enforcement against youth suspected of even minor criminal activity. Still others attempted to change youth behavior through "soft" strategies built on alternatives to arrest. Finally, some cities used a combination of approaches. Key findings discussed in this article include:

- Law enforcement agencies that emphasized police-citizen cooperation benefited from a more positive image and sense of legitimacy in the community, which may have enhanced their efforts to fight crime.

- Aggressive law enforcement strategies may have contributed to a decline in youth gun violence, but they also may have cost police legitimacy in minority communities where residents felt that the tactics were unfair or racially motivated.

- Approaches that emphasize nonarrest alternatives and problem-solving strategies offer an intriguing but unproven vision for addressing youth gun violence.

$\mathrm{N}$ one of the initiatives presented in the case studies has been shown conclusively to reduce youth gun crime over the long term. The author suggests that policing alone cannot contain youth gun violence, but by carefully balancing enforcement with community collaboration, police departments can help shift social norms that contribute to youth gun violence.

J effrey Fagan, Ph.D., is professor of law and public health at Columbia U niversity Law School. 
T

he epidemic of youth gun violence in the U nited States from 1985 to 1998 triggered a crisis of social and political consequences that mobilized legal institutions to develop effective policies and programs targeting youth violence. ${ }^{1}$ Even before this most recent homicide crisis, however, numerous experiments and innovations in policing had been taking place in cities across the $U$ nited States; some of these were quickly adapted in the effort to combat youth gun violence. ${ }^{2} \mathrm{U}$ nder the flag of "community policing," "problem-oriented policing," and "order-maintenance policing," police departments launched a variety of new approaches to chronic problems of crime and disorder. Youth gun violence was often the focus of these reforms and experiments.

These initiatives ranged from intensive and aggressive street-level interdiction of low-level disorder to new forms of neighborhood-police partnerships, often called "community policing." ${ }^{3}$ Several of these efforts were designed in response to an influential essay on "Broken Windows," which described the contagious effects of disorder on crime. ${ }^{4}$ (See Box 1 later in this article.) Other programs focused on specific individuals and high-crime neighborhoods. ${ }^{5}$ Still others sought to expand the toolkit of police to include solving social problems through interaction and collaboration with citizens. ${ }^{6}$ In these strategies, police focused their efforts on issues that concerned residents the most, while motivating citizen cooperation in the everyday policing of crime.

This article presents eight case studies (see Table 1) of cities where policing innovations were targeted at gun violence. It summarizes the underlying conceptual framework of each effort and describes both its strategies and its specific focus on youth violence. ${ }^{7}$ Evaluation data are limited, but when available, the results of each initiative are reported. These case studies suggest three different approaches to strengthening social control to reduce youth gun violence:

D eciprocal Control. Cities that adopted this approach to policing gun violence, including Boston, C hicago, and San Diego, aimed to make the crime-control activities of police and community groups mutually reinforcing. Power-sharing arrangements evolved between police and citizens through a process of problem solving and collective decision making.
D Punitive Legal Control. The punitive approach focused on deterring gun violence through vigorous law enforcement. N ew York City emphasized aggressive street-level enforcement to detect and remove guns through intensive surveillance and high arrest rates. Project Exile in Richmond pursued aggressive prosecution strategies against gun offenders. In these cases, citizens were often excluded from the process of designing strategy, and citizen perspectives were of secondary importance in setting policy.

D "Soft" Legal Control. This approach emphasized community-driven, nonarrest methods to reduce youth gun crime. The Firearm Suppression Program in St. Louis implemented voluntary searches of homes where juveniles were suspected of keeping weapons. In D etroit, the juvenile courts adopted a therapeutic, rather than a punitive, approach to encouraging juvenile gun offenders to put down their weapons. Police collaboration with mental health professionals to address gun-related trauma in $\mathrm{New} \mathrm{H}$ aven also featured the systematic use of nonarrest alternatives to prevent youth gun violence. These efforts helped to mitigate cultural and social barriers between police and citizens.

In several cities, these social control strategies overlapped. Cities such as Boston and Chicago, for example, used both reciprocal and punitive policing strategies. They incorporated both community involvement and intensive surveillance, and enforcement focused on high-risk offenders in specific neighborhoods. Similarly, well-publicized innovations in community policing in San Diego were credited with the lion's share of that city's reduction in violence through the 1990s and were offered as a positive contrast to $\mathrm{New}$ York City's aggressive model. ${ }^{8}$ But intensive enforcement efforts targeted at street gangs and drug traffickers were also a focus in San D iego throughout this period. ${ }^{9}$

The innovations in police responses to youth gun violence described in this article reflect diverse theories not just of organizational change, but also of how citizens and police might interact to produce security and social control. As these case studies illustrate, police-citizen interactions can influence the course of youth gun violence outbreaks. 


\section{Table 1}

\section{Police Approaches to Curbing Youth and/or Gun Violence}

\begin{tabular}{|c|c|c|c|c|}
\hline Name of Initiative & Location & Key Participants & $\begin{array}{l}\text { Policing } \\
\text { Strategy }\end{array}$ & Program Description \\
\hline $\begin{array}{l}\text { The Boston } \\
\text { Gun Project }\end{array}$ & Boston, MA & $\begin{array}{l}\text { Boston Police Depart- } \\
\text { ment, other criminal } \\
\text { justice agencies, Harvard } \\
\text { University, Ten Point } \\
\text { Coalition }\end{array}$ & $\begin{array}{l}\text { Reciprocal, } \\
\text { punitive }\end{array}$ & $\begin{array}{l}\text { Targeted young gang members and other offend- } \\
\text { ers; deterred illegal activity by informing potential } \\
\text { offenders that even minor infractions would result } \\
\text { in a massive police response; worked with } \\
\text { churches to create legitimacy for police efforts. }\end{array}$ \\
\hline $\begin{array}{l}\text { Chicago } \\
\text { Alternative } \\
\text { Policing Strategy } \\
\text { (CAPS) }\end{array}$ & Chicago, IL & $\begin{array}{l}\text { Chicago Police Depart- } \\
\text { ment, district advisory } \\
\text { councils composed of } \\
\text { community residents }\end{array}$ & $\begin{array}{l}\text { Reciprocal, } \\
\text { punitive }\end{array}$ & $\begin{array}{l}\text { Created citizen councils to advise each police dis- } \\
\text { trict; held monthly meetings with citizens in each } \\
\text { police "beat"; coincided with aggressive police } \\
\text { enforcement of anti-loitering ordinance aimed at } \\
\text { gang members. }\end{array}$ \\
\hline
\end{tabular}

$\begin{array}{lll}\begin{array}{l}\text { Neighborhood } \\ \text { Policing }\end{array} & \text { San Diego, CA } & \text { San Diego Police } \\ & \text { Department, San Diego } \\ & \text { Organizing Project }\end{array}$

Reciprocal Incorporated extensive community involvement into policing; supported Neighborhood Watch programs; collaborated with community organizations to clean up properties that attracted criminal activity; trained volunteers in crime prevention; assigned police officers to schools to work on community-identified problems.

\begin{tabular}{|c|c|c|c|c|}
\hline $\begin{array}{l}\text { Order- } \\
\text { Maintenance } \\
\text { Policing }\end{array}$ & New York, NY & $\begin{array}{l}\text { New York City Police } \\
\text { Department }\end{array}$ & Punitive & $\begin{array}{l}\text { Aggressively enforced laws against social disor- } \\
\text { der with frequent use of "stop-and-frisk" tactics } \\
\text { to identify lawbreakers, and with mandatory } \\
\text { arrest for even low-level crimes. }\end{array}$ \\
\hline Project Exile & $\begin{array}{l}\text { Richmond, VA; } \\
\text { similar programs } \\
\text { in other locations }\end{array}$ & U.S. Attorney's office & Punitive & $\begin{array}{l}\text { Prosecuted all gun-related arrests made by state } \\
\text { and local authorities in federal court, where } \\
\text { penalties are often more serious. }\end{array}$ \\
\hline $\begin{array}{l}\text { Firearm } \\
\text { Suppression } \\
\text { Program }\end{array}$ & St. Louis, MO & $\begin{array}{l}\text { St. Louis Police } \\
\text { Department }\end{array}$ & Soft & $\begin{array}{l}\text { With parental consent, searched homes and con- } \\
\text { fiscated illegal weapons from juveniles; did not } \\
\text { charge parents who allowed searches with illegal } \\
\text { firearm possession. }\end{array}$ \\
\hline $\begin{array}{l}\text { Therapeutic } \\
\text { J urisprudence }\end{array}$ & Detroit, MI & Detroit juvenile courts & Soft & $\begin{array}{l}\text { Required youth gun offenders to attend a class } \\
\text { that emphasized the danger of handguns and the } \\
\text { importance of personal responsibility in reducing } \\
\text { gun violence. }\end{array}$ \\
\hline $\begin{array}{l}\text { Child Develop- } \\
\text { ment- Community } \\
\text { Policing Program }\end{array}$ & New Haven, CT & $\begin{array}{l}\text { New Haven Police } \\
\text { Department, Yale } \\
\text { University School of }\end{array}$ & Soft & $\begin{array}{l}\text { Trained police officers in mental health and child } \\
\text { development to help children who were victims or } \\
\text { witnesses of gun violence cope with trauma. }\end{array}$ \\
\hline
\end{tabular}




\section{Reciprocal Control: Boston, Chicago, and San Diego}

Throughout the 1990s, police departments in Boston, Chicago, and San Diego focused heavily on citizen involvement as a way to reduce youth gun violence. In each of these communities, increased collaboration between citizens and the police may have increased the legitimacy of the police in the eyes of the community. Although the mechanisms for citizen participation varied from city to city, a common thread was cooperation between citizens and police in developing solutions to the problems that contributed to youth violence.

\section{The Boston Gun Project}

In Boston, police sought to combat youth gun violence by deterring gang members from engaging in illegal activity. The Boston strategy also incorporated extensive outreach to religious and community leaders in the African American, inner-city neighborhoods where most youth gun violence was taking place. The Boston Gun Project helped to increase legitimacy for the police department in communities that have historically mistrusted the police, but this process remains far from complete.

Two distinct and contrasting narratives comprise the Boston story. In one, the Boston Police Department formed an interagency working group, composed of $\mathrm{H}$ arvard $\mathrm{U}$ niversity researchers, the police department, and other criminal justice agencies, to collaborate on research and analysis of the city's youth violence problem. The work of this group showed that the problem was concentrated among a small group of high-rate offenders who were deeply involved in Boston's youth gangs. ${ }^{5}$

In response, the working group developed a strategy called "pulling levers," which employed a deterrence model to curb youth violence. Police and probation officers communicated directly to gang members that any wrongdoing would be met with swift and immediate sanctions, including arrest and prosecution for even small infractions as well as the quick revocation of probation or parole for either minor or major violations. The project deterred youth gun violence both by making good on the promise of strong legal reactions to any crime and by saturating neighborhoods with this message via fliers, street work with individual gang members, and group interactions with agency staff from the probation department. ${ }^{10}$

By generalizing deterrence throughout gangs, not just for a few members whose violence had captured the attention of probation and police officers, the initiative sought to create a shift in norms within Boston's youth gangs, encouraging gang members to restrain each other from violent activity. Because the actions of one gang member would trigger a crackdown by police and probation staff on all members of that gang, gangs had a powerful incentive to rein in violent members.

The second narrative in the Boston story was the construction of an "umbrella of legitimacy" that permitted a reconciliation of the interests of the police and the inner-city community that was the focus of the Boston Gun Project. ${ }^{11}$ The racialized political climate in Boston-going back to the city's school desegregation conflict and a series of scandals over unfair police treatment of A frican American males-made it necessary to establish a new climate in which inner-city citizens could embrace and participate in police efforts. ${ }^{12}$ The Boston Gun Project sought to build legitimacy for police efforts to end youth gun violence through close interaction with the Ten Point Coalition, a group of Boston ministers from 40 inner-city churches. ${ }^{11,13}$ The partnership made sense because the Ten Point Coalition and Boston's law enforcement agencies had reciprocal and aligned goals. ${ }^{11}$ Active offenders had undermined the ministers' efforts to reach high-risk youth, while the police needed acceptance by residents of Boston's inner-city neighborhoods to succeed in their surveillance efforts.

The Coalition engaged with law enforcement agencies to instill community norms opposing violence. The Coalition retained its credibility in the community by maintaining its independence from the police-even criticizing the police- while at the same time working with the police to reach out to at-risk or criminally active youth. Through its contacts with citizens and adolescents, the Coalition has continued to show its disapproval for violence and its desire to keep other youth out of trouble. ${ }^{11,14}$ 
Although the Boston police can now operate in the slipstream of the Coalition's efforts, legitimacy continues to be an elusive goal for them. According to ethnographic research in Boston's inner-city communities, citizens now view the police as competently and dependably enforcing law in their neighborhoods, but they also feel that the police show "disrespect," 15 targeting their children for policing and conveying the impression that police efforts are designed to control community residents and protect "others." 15 Residents reported that fair and respectful treatment was important to their ratings of their security and was a factor that motivated or impeded their compliance with police and with the law. ${ }^{16}$ The prospects for long-term success from this unique collaboration of churches and the law may lie in the extent to which reciprocal interests and mutual respect are sustained between citizens and police.
Did the Boston Gun Project reduce youth firearm homicide rates more effectively than efforts in other $M$ assachusetts cities? Figure 1 shows that firearm homicides of persons under age 25 declined sharply following the launch of the Boston Gun Project in June 1996 and continued to decline through 1997 before rising again in 1998. However, youth gun homicides in Boston had begun declining in 1995, the year preceding the Boston Gun Project. Also, youth gun homicides declined in other $M$ assachusetts cities during this same period. In cities with populations from 75,000 to 175,000 , youth gun homicide victimization rates had declined nearly $75 \%$ by 1998 , compared to a $50 \%$ decline in Boston. The declines in Boston thus seem to have been part of a larger statewide downward trend in youth gun violence. Moreover, homicides in Boston have continued to rise since 1998.

\section{Figure 1}

\section{Firearm Homicide Victimization Rate, Ages 0 to 24}

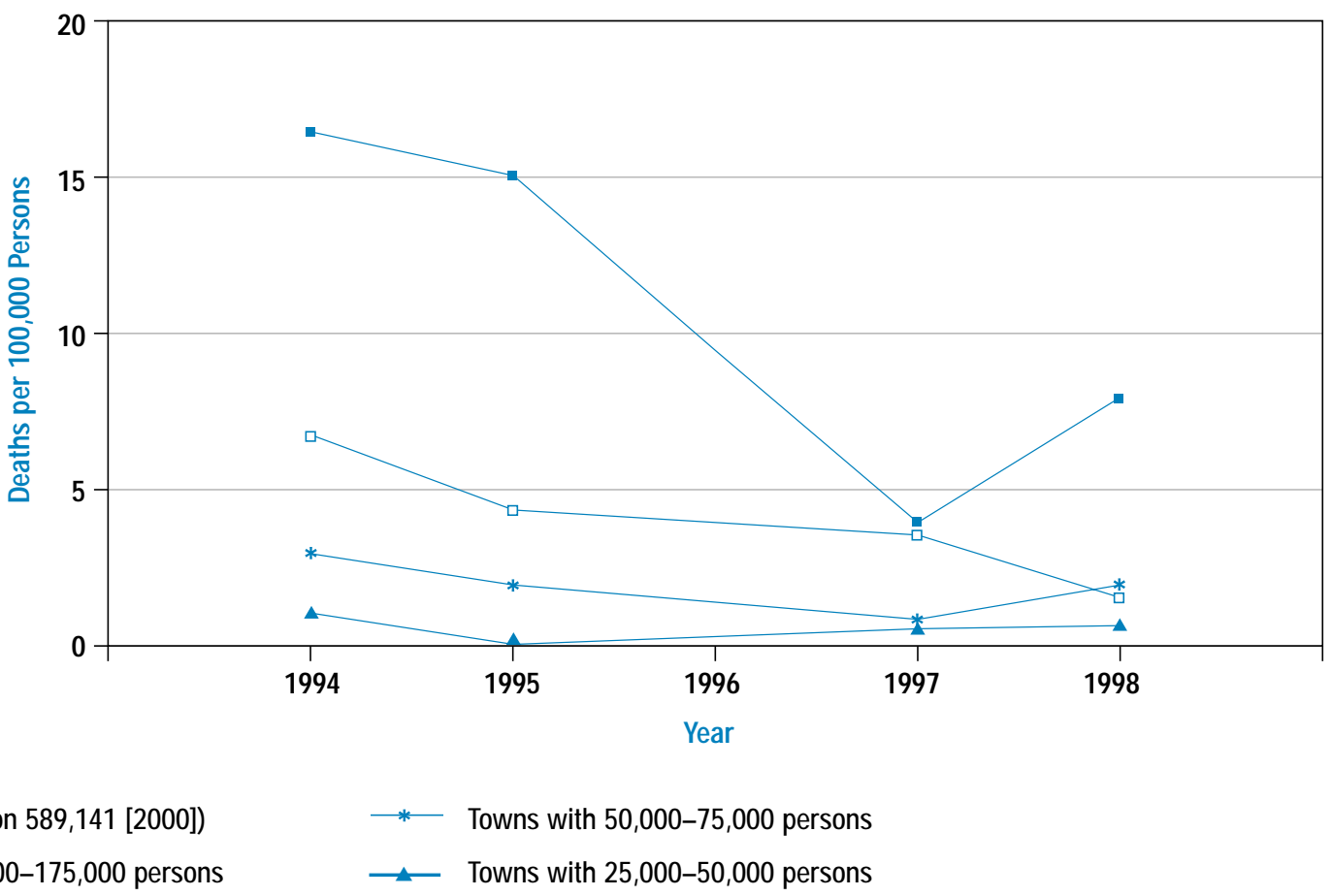

Source: Massachusetts Department of Health, Weapon-Related Injury Surveillance System (WRISS); Massachusetts Institute for Social and Economic Research, 1997 population estimates and projections. 
The future of the Boston G un Project is uncertain. The Coalition of police and clergy faces new problems, including an economy in recession, a return of youth gun violence, and a large cohort of newly released prisoners returning to Boston's inner city. H ow past successes evolve to meet these new challenges will be a critical test of the validity of the Boston strategy.

\section{Chicago's Community Policing Experiment}

Similar to Boston's experience, two narratives unfolded in Chicago. O ne exemplified "community policing": police-community interactions to reduce crime and support social control. The other incorporated proactive policing of high-risk juvenile and young adult gang members. Although these two approaches to policing were not targeted specifically at youth, they affected policing of youth crime and adolescent gun violence significantly. The two approaches reflected very different visions about the role of citizens in controlling crime and the possibilities for police-citizen collaboration in the coproduction of security.
Known as the $\mathrm{C}$ hicago Alternative Policing Strategy, or CAPS, the community policing experiment structured systematic citizen-community interactions at the beat and district levels. Chicago is divided into 26 police districts, which are further divided into 279 beats, each delineating the patrol area of one squad car. ${ }^{17}$ Beginning in January 1993, the first of five prototype districts began implementing CAPS. The prototype districts stressed "beat integrity," which meant that officers focused service on their patrol areas. They did not patrol areas outside their beat; individuals were assigned to particular beats for sustained periods; police officers knew the problems and residents of their beats; and residents got to know them.

At monthly meetings in each beat, police met with residents to jointly identify and strategize about the most urgent problems of crime and disorder in their neighborhoods. ${ }^{18}$ Each district also created an advisory body of community leaders to represent larger concerns to the district's commander. The prototype program was hailed as a success and expanded to cover the entire city beginning in fall $1994 .{ }^{17}$ Approximately 80,000 people attended beat meetings during 1995 and the first four months of $1996 .{ }^{19}$

CAPS was an experiment not just in community policing, but also in democracy. ${ }^{20}$ By creating a new democratic deliberative forum, in which agencies and citizens worked together to set enforcement priorities, CAPS offered the promise of accountability of police to citizens. Participation by residents in beat meetings and district advisory councils varied by neighborhood and over time, however. ${ }^{21} \mathrm{~A}$ study of 15 of the 279 police beats found uneven implementation of the CAPS strategy: Four beats were doing well, five showed some successes in implementation, two were "struggling," and four had done nothing at all. ${ }^{22}$ The study attributed the variation to individual differences in the officers assigned to CAPS functions.

Even so, citizens reacted positively to the CAPS efforts. A U .S. D epartment of J ustice survey reported that nearly three in four Chicago residents were familiar with the term "community policing," two in three stated that the police were actually doing "community policing," and two in five had heard about the monthly beat meetings. ${ }^{23}$ 


\section{Safety is only one dimension on which citizens evaluate police actions, and fair treatment may perhaps be a more important factor.}

As the CAPS experiment was unfolding, another police initiative sought to eliminate gang activity in Chicago's most troubled neighborhoods. Chicago's M ay 1992 Gang Congregation Ordinance prohibited "criminal street gang members" 24 from loitering in public places. ${ }^{25}$ U nder the ordinance, police officers could order the dispersal of two or more persons loitering in a public place if the officers reasonably believed that at least one of the persons was a gang member. Failure to promptly obey such an order was a violation of the ordinance and could result in arrest.

U Itimately, the U.S. Supreme Court found the Gang Congregation Ordinance to be unconstitutional, ${ }^{26}$ but only after nearly 40,000 persons had been arrested. ${ }^{27} \mathrm{~A}$ 1995 study of two of Chicago's 26 police districts estimated that $27 \%$ of the African American male youth population had been arrested under the ordinance in one district, and $34 \%$ in the other. ${ }^{28} \mathrm{~N}$ or did the ordinance appear to have the desired effect of reducing crime. While it was in effect from 1992 to 1995, murders rose by $2.9 \%$ in the three districts with the highest arrest rates, but declined by $54.5 \%$ in the three districts with the lowest arrest rates. ${ }^{28}$

In 2000, a revised ordinance was adopted that addressed the U .S. Supreme Court's criticisms. The revised ordinance more carefully spells out the circumstances under which police officers can issue an order to disperse, and it more narrowly defines suspicious behaviors that warrant police attention. It remains in effect today.

Some argue that the Gang Congregation Ordinance reflected the wishes of community members who were victims of gang violence and could not participate in everyday social regulation of neighborhood activities because of fears for their safety. ${ }^{29} 0$ thers argued that the initiative discriminated against youth in minority communities and gave broad, unregulated power to the police to detain and arrest young people. The strategy of aggressive enforcement of a vague law undermined the legitimacy of policing through its broad reach to intervene in behavior at the very lowest thresholds of criminal law violation. ${ }^{30}$ Safety is only one dimension on which citizens evaluate police actions, and fair treatment may perhaps be a more important factor. ${ }^{31}$ In this algebra, it is unlikely that policies like the Gang Congregation O rdinance can produce legitimacy and promote compliance with the law among inner-city residents, even if they may promote safety.

D espite these concerns, the $\mathrm{G}$ ang Congregation $\mathrm{O}$ rdinance appears to reflect the future of policing in Chicago. In 2001, Chicago recorded 666 homicides, its first increase since 1994 and the highest total of any city in the nation. Concerned over rising homicide rates, police officials have shifted their strategy to concentrate on the gang problems that drive Chicago's homicides, using aggressive street-level enforcement techniques sanctioned by the ordinance. It remains to be seen whether the CAPS style of police-citizen cooperation in crime control can coexist with this aggressive form of policing-or whether CAPS will be eclipsed entirely. ${ }^{32}$

\section{Neighborhood Policing in San Diego: The Coproduction of Security}

Police officials in San Diego adopted the theory and operating principles of community policing, structuring police-citizen interactions to strengthen informal social control and prevent crime. Efforts to reduce youth gun violence were a key part of their strategy, but the police focused on prevention, using arrest only after other approaches failed.

San Diego began a community-policing experiment, the Neighborhood Policing Philosophy, in the late 1980s. In 1993, the department was reorganized, and the entire force retrained to implement community policing. ${ }^{8}$ The San Diego reform was focused not on specific crime problems such as gun violence or youth crime, but instead on the creation of a systemic process of police-citizen interactions to maximize social control. The result was a reciprocal process, with police and citizens closely aligned in pursuit of shared goals.

The San Diego Police Department's strategy included sharing information with citizens for analysis of crime problems, forming partnerships with community groups to address problems that motivate or facilitate crime, and emphasizing routine, noncoercive police contacts with 
citizens to share responsibility for crime prevention and control. This approach shifted the police department's emphasis from traditional surveillance-investigationapprehension to identification and remediation of the social and physical conditions that facilitate crime.

Partnerships between the police and citizens were forged among elites in government, labor, education, and citizen groups, and were replicated at the local level. A steering committee was formed in 1993 to guide the reform, and at the same time, community advisory boards were formed, mirroring the larger group. The San D iego O rganizing Project, a citywide advocacy group, provided leadership to legitimize the collaboration with the police.

The neighborhood policing strategy in San Diego included the common elements of community policing elsewhere: (1) support for "neighborhood watch" and citizen patrol groups to look for suspicious activity, identify community problems, and work on crime-prevention projects; (2) use of civil remedies and strict building code enforcement to abate nuisances such as drug markets or drug-use locations; and (3) collaboration with community organizations and local business groups to clean up, close down, or redesign locations and properties that repeatedly attracted prostitution, drug, and gang problems. ${ }^{9}$

What set the San D iego reform apart from other community policing efforts was the role embraced by organized neighborhood volunteers. The San Diego Police D epartment recruited and trained a pool of more than 1,000 citizen volunteers to perform a broad array of crime-prevention and victim-assistance services. Accordingly, the San Diego experiment integrated community policing with community participation. ${ }^{9}$

Specific efforts to reduce youth gun violence in San D iego began in 1997 with the formation of a task force of 200 people, including representatives from police, probation, schools, the juvenile court, parents, community advisory boards, and nonprofit groups. The task force created juvenile service teams, with officers placed in schools to focus on needs identified by the community advisory boards. The teams referred youth at risk of gun violence to local service providers. In addition, a gang-suppression team focused on the city's estimated 5,000 gang members, who were involved in a large share of youth gun injuries, and a narcotics task force focused on violence in drug markets.

These teams pursued a crime-prevention strategy based on community perspectives that arrests failed to offer long-term solutions to youth gun violence. ${ }^{9}$ Similar to the Ten Point Coalition and the Boston Gun Project, the teams placed a wide net of social control over youth before they became involved with gun violence. Legal sanctions were used as a last resort to address problems that had failed to respond to other nonarrest solutions.

The San D iego effort has not been fully evaluated, but it offers a compelling vision of how a police department can fully involve its citizens in making communities safer. Extensive community participation and the police department's nonpunitive approaches toward reducing youth gun violence spared San Diego much of the ill will and mistrust spawned by aggressive policing tactics in $\mathrm{N}$ ew York $\mathrm{C}$ ity-the next focus of this article.

\section{Punitive Legal Control: New York City and Richmond}

The punitive approach aims to deter youth gun violence through aggressive law enforcement against all offenders, even those who have committed low-level crimes. Although both Boston and Chicago included punitive components in their law enforcement strategies, they also used other tools to combat gun violence. In contrast, $\mathrm{N}$ ew York City and Richmond relied primarily on punitive strategies. In both cities, rates of gun violence fell precipitously, with punitive strategies getting much of the credit for the drop. However, because these strategies fail to involve the community or change the dynamics of citizen participation in crime control, punitive approaches do not hold the promise of reducing youth gun violence in the long term.

\section{Order-Maintenance Policing in New York City}

Beginning in 1994, New York City police officials redesigned crime-control strategies to focus on two related problems: (1) social and physical disorder and (2) gun violence. The police adopted a strategy known as "order-maintenance policing" (OMP), which focused on fighting crime by targeting low-level disorder. The $\mathrm{New}$ York Police Department (NYPD) 
cracked down on low-level crime through aggressive enforcement measures; hundreds of thousands of $\mathrm{N} \mathrm{ew}$ Yorkers-including large numbers of adolescentswere subject to stop-and-frisk actions under this policy. The OMP approach was credited with significant declines in gun violence in $\mathrm{N}$ ew York City in the midto late 1990s. But this success came at a price: increased community mistrust of police and perceptions that the police were engaging in racial profiling.
$\mathrm{N}$ ew York C ity's OM P strategy derived from what has become popularly known as Broken Windows theory. ${ }^{33,34}$ (See Box 1.) U nder OM P, police aggressively enforced laws against social disorder with "zero tolerance," requiring arrest for any law infraction. ${ }^{35}$ Lowlevel offenses that required arrest under the policy included graffiti, aggressive panhandling, fare beating, public drunkenness, unlicensed vending, public drinking, and public urination.

\section{Box 1}

\section{The Broken Windows Theory of Policing}

Broken Windows theory has had an extraordinary influence on American policing in the past two decades - in New York City and many other cities. The theory, originated by Professors J ames Q. Wilson and George Kelling, has also stimulated a body of academic writing on the subject of order maintenance. ${ }^{a}$

Because signs of physical and social disorder invite criminal activity, Wilson and Kelling argue, police should address minor disorders to strengthen police-citizen interactions and promote informal social control. ${ }^{\mathrm{b}, \mathrm{c}}$ Disorder indicates to law-abiding citizens that their neighborhoods are dangerous places, making these citizens afraid to take an active role in promoting social order in their communities and leading them to withdraw from community life. ${ }^{d}$ At some tipping point, the theory suggests, disorder trumps order by defeating the willingness of citizens to interact with the police to promote security. Disorder invites more disorder in a contagious process that progressively breaks down community standards and ultimately invites criminal invasion.

Theories about how social norms work suggest that individuals create norms of either legal or illegal behavior in their communities through interactions with others. ${ }^{e}$ Broken Windows theory calls for changing social norms in communities where crime is pervasive, removing the cues of crime (such as vandalism, petty theft, and loitering), and replacing those cues with alternative cues that signal order and social regulation. Citizen-police collaboration is a critical element in the theory; citizens engage with police to enforce norms of orderliness. ${ }^{f}$ When police focus on repairing or removing low-level disorder problems, Wilson and Kelling argue, they combat crime by promoting social interactions among law-abiding citizens; this, in turn, strengthens the dynamics of social regulation that produce security and social control. ${ }^{g}$

\footnotetext{
a See, for example, Kelling, G.L. Order maintenance, the quality of urban life, and police: A line of argument. In Police leadership in America. W.A. Geller, ed. Westport, CT: Praeger, 1985; Klockars, C.B. Order maintenance, the quality of urban life, and police: A different line of argument. In Police leadership in America. W.A. Geller, ed. Westport, CT: Praeger, 1985; Klockars, C.B. Street justice: Some micro-moral reservations: Comment on Sykes. J ustice Quarterly (December 1986) 3(4):513-16; Sykes, G.W. Street justice: A moral defense of order maintenance policing. J ustice Quarterly (December 1986) 3(4):497-512; Sykes, G.W. The myth of reform: The functional limits of police accountability in a liberal society. J ustice Quarterly (March 1985) 2(1):51-66; and Greene, J.R., and Taylor, R.B. Community-based policing and foot patrol: Issues of theory and evaluation. In Community policing: Rhetoric or reality? J .R. Greene and S.D. Mastrofski, eds. New York: Praeger, 1988, pp. 195, 201-03.

b Wilson, J.Q., and Kelling, G.L. The police and neighborhood safety: Broken windows. Atlantic Monthly (1982) 249(3):29-38. Wilson and Kelling's definition of "minor" disorder includes such problems and crimes as littering, loitering, public drinking, panhandling, teenage fighting on street corners, and prostitution. Also mentioned are signs of physical disorder, including abandoned cars (with broken windows, naturally) and dilapidated buildings (also with broken windows).

C Livingston, D. Police discretion and the quality of life in public places: Courts, communities, and the new policing. Columbia Law Review (1997) 97:551-672; Waldeck, S.E. Cops, community policing, and the social norms approach to crime control: Should one make us more comfortable with the others? Georgia Law Review (2000) 34:1253-1310; and Harcourt, B.E. Reflecting on the subject: A critique of the social influence conception of deterrence, the broken windows theory, and order-maintenance policing New York style. Michigan Law Review (1998) 97(2):291-356.

d See note no. 2, Wilson and Kelling, p. 33.

e Meares, T.L., and Kahan, D.M. Law and (norms of) order in the inner city. Law and Society Review (1998) 32(4):805-31. For an illustration based on ethnographic research, see Anderson, E. Code of the streets. New York: Norton, 1999.

f See note no. 5, Meares and Kahan, p. 823.

g Ellickson, R.C. Controlling chronic misconduct in city spaces: Of panhandlers, skid rows, and public-space zoning. Yale Law J ournal (1996) 105(5):1165-1248.
} 


\section{Although stop-and-frisk tactics most likely contributed in part to the crime decline in $\mathrm{N}$ ew York City, their precise contribution is contested.}

This policy was very different from traditional notions of community policing. Typically, community policing has emphasized citizen-police collaboration to reduce social disorder; avoidance of coercive encounters with citizens on the street; and efforts to remedy physical disorder in the community through activities such as cleaning up trash-strewn lots, painting over graffiti, or correcting code violations in buildings. ${ }^{36}$ Instead, the NYPD adopted a policy of aggressive stop-and-frisk practices. In practice, the policy evolved as gun-oriented policing based on aggressive stops and searches of people suspected of carrying guns illegally or committing even minor infractions. $^{37,38}$ With nearly all increases in homicides, robberies, and assaults during this period attributable to gun violence, it is not surprising that the NYPD focused on guns. $^{37}$ (See the article by Blumstein in this journal issue.) The homicide crisis was a critical theme in the mayoral election campaign of 1993 and focused the attention of the incoming Giuliani administration's crime-control policy on gun violence. ${ }^{39}$

This tactical shift toward aggressive stops and searches departed sharply from the pristine version of Broken Windows theory, as well as from the original version of $\mathrm{OMP}$ and other models of community policing. ${ }^{40} \mathrm{As}$ originally conceptualized, OM P involved the enforcement of community standards "through non-arrest approaches-education, persuasion, counseling, and ordering-so that arrest would only be resorted to when other approaches failed." ${ }^{41} \mathrm{~N}$ ew York City's policy ultimately violated the principles of OMP in two ways. First, the NYPD version of OMP rejected the emphasis on alternatives to arrest and prosecutionessential tenets of the theory. ${ }^{42}$ Second, community standards were not identified through structured and systematic interactions between police and community leaders. Instead, the NYPD turned to a sophisticated data-driven management accountability system to identify community needs.

The focus on guns nudged OM P in New York City into a pattern of racial policing. Because disorder is more often prevalent in urban neighborhoods with elevated rates of poverty and social fragmentation, ${ }^{43}$ OM P tactics were disproportionately concentrated in minority neighborhoods, where disorder and crime were conflated with poverty and socioeconomic disadvantage. M inority citizens thus widely perceived OM P as racial policing or racial profiling. ${ }^{44}$ The fact that the principal tactic was an aggressive form of stop-and-frisk policing involving intrusive searches ${ }^{45}$ and that at least two deaths of unarmed citizens of African descent were linked to OMP ${ }^{46}$ further intensified perceptions of racial animus. ${ }^{47}$

In other words, New York City's implementation of Broken Windows theory produced a style of racial policing that stigmatized minority communities and widened an already-troubling racial breach in the city. ${ }^{48}$ Although stop-and-frisk tactics most likely contributed in part to the crime decline in N ew York City, their precise contribution is contested. ${ }^{49}$ But there also is little doubt that there were social costs from the crackdown on crime, which may have compromised the original intent of Broken Windows theory: to rebuild social norms against crime. ${ }^{31}$ As one researcher observed, these efforts "have little to do with fixing broken windows and much more to do with arresting window breakers- or persons who look like they might break windows, or...strangers...or outsiders." 50

\section{Prosecution of Gun Offenders in Richmond}

From time to time, federal prosecutors have pursued a strategy of selective federalization of high-profile crimes that otherwise would fall under state jurisdiction, using the significant prosecutorial resources of the federal branch to increase the likelihood of conviction and lengthier sentences. One such effort, Project Exile, is targeted at gun violence. Project Exile was conceived in the late 1980s in the U .S. Attorney's office encompassing Richmond and the surrounding regions of Virginia. Although the program in its original form was not targeted specifically at youth, some communities have adapted it to focus on youth. Project Exile has been credited with declines in gun violence. It includes little community involvement, however, which makes it dif- 
ficult for the program to change youth cultural norms surrounding guns. M oreover, new studies suggest that the program's successes may have been overstated.

In Project Exile's original form, all gun arrests made by state and local authorities were prosecuted in federal court under federal firearms statutes, which were more stringent than state laws and allowed for longer prison sentences. ${ }^{51}$ To increase its general deterrent effect, Project Exile was implemented with "an innovative community outreach and education initiative...to get the message to criminals that illegal guns are unacceptable and will not be tolerated." 52

Both 2000 presidential candidates embraced Project Exile, and politicians from both parties have endorsed the program, lauding what they see as its successes..$^{53}$ Indeed, the initial results of Project Exile seemed impressive. Prosecutors obtained 59 indictments within two weeks of launching the project, ${ }^{54}$ and firearms seizures declined by $50 \%$ within three months. ${ }^{55}$ Within two years, 438 indictments had been obtained, ${ }^{52}$ and Project Exile was associated with a $33 \%$ reduction in the homicide rate over a two-year period. ${ }^{56}$ In 1999 , the Justice Department sought resources to expand Project Exile in a limited way. Funds were allocated for hiring federal prosecutors, but none of the other program elements (such as outreach efforts to the community) were included.

U nfortunately, recent studies show that declines in gun violence produced under Project Exile were no greater than the general decline in gun violence throughout U.S. cities during that time. ${ }^{57}$ The decline in Richmond's gun homicide rates represented a continuation of the general downward trend in gun homicides in that city during the years preceding Project Exile and was not unusual compared to the declines in gun homicides in other cities during the same years. Broad reductions in gun violence were consistent in most of the nation's large cities during the late 1990s, regardless of whether Project Exile or similar programs were in effect.

D espite mixed evidence of its impact, Project Exile has inspired several other programs nationwide. O peration Safe N eighborhoods (OSN) in Baltimore, for example, 
seeks to identify and prosecute high-risk individuals involved in gun violence and gun trafficking. ${ }^{58} \mathrm{As}$ in Project Exile, the agencies involved in OSN have made a concerted effort to directly "deliver this message" 59 to offenders. Community organizations and faith institutions are involved to address conditions that give rise to gun violence, a strategy similar to that used in Boston. Prosecution, however, is clearly at the forefront of the program. Like Project Exile, OSN is not specifically targeted at juveniles.

Another program, the Youth Violence $\mathrm{H}$ andgun Initiative in Seattle, does focus on adolescents and uses selective prosecution to address youth gun crime problems. ${ }^{60}$ Several studies suggest that prosecution became more efficient under this initiative. Charges were filed more quickly, case-processing time was reduced, and conviction rates increased from $65 \%$ to $78 \%{ }^{61}$

Project Exile and similar programs make conscious efforts to respond to gun violence problems with highly visible and strong punishment and to deter wouldbe youth gun offenders by communicating the high odds that gun possession or gun crimes will evoke punishment. Prosecution does not address safety issues that pervade the developmental ecology of adolescents when gun violence is common in their communities, however. (See the article by Garbarino, Bradshaw, and Vorrasi in this journal issue.) Though such efforts may ensure that justice is done to youth gun offenders, they are not likely to change the scale of youth gun violence or the presence of guns in youth culture significantly. D eterrence messages often are trumped by danger on the streets and the perception of teenagers that they need to carry arms for their own safety. ${ }^{62,63}$

\section{Soft Legal Control: St. Louis, Detroit, and New Haven}

Some law enforcement agencies have tried to reduce youth gun violence in their communities by emphasizing nonpunitive "soft" approaches, with arrest and incarceration available as a last resort when other approaches fail. Three cities-St. Louis, D etroit, and $\mathrm{N}$ ew $\mathrm{H}$ aven-adopted innovative "soft" strategies to address youth gun violence in the 1990s. Although these strategies had mixed records at reducing youth gun crime, they offer compelling visions for how police can expand their toolkits when working with youth.

\section{Consensual Gun Searches in St. Louis}

The St. Louis Firearm Suppression Program (FSP) incorporated the concepts of community involvement from Chicago and Boston to develop a gun-oriented policing policy that was precisely the opposite of the policy in N ew York City. ${ }^{64} \mathrm{O}$ perated by the St. Louis Police D epartment, FSP was a "knock-and-talk" program that elicited parental consent to enter homes to search for and seize guns from juveniles. ${ }^{65}$

The program was straightforward. Responding to a request from a parent, or a report from a neighbor, FSP officers would visit the home and ask an adult resident for permission to conduct a search for illegal weapons. The officers would explain that the search was intended solely to confiscate illegal firearms, particularly those belonging to juveniles, and that there would be no criminal prosecution. A "Consent to Search and Seize" form allowed police to enter the home legally and conduct the search. ${ }^{66}$ Adult residents also were told that they would not be charged with illegal firearm possession if they signed the consent form. ${ }^{66}$

As in Boston, Chicago, and San Diego, the St. Louis effort reflected an analysis of youth gun violence problems by police in collaboration with the community. Indeed, researchers have characterized the program as "a response to problems identified by citizens." ${ }^{66} \mathrm{H}$ owever, citizens participated in a limited way in this experiment, by consenting to police searches, in contrast to the structured community interactions of citizens and police in problem solving in other cities.

The St. Louis strategy differed from New York City's aggressive, order-maintenance policing strategy by narrowly constructing targets and focusing efforts on welldefined situations. By avoiding broad suspicion based on crime demography, the St. Louis police minimized the possibility of mistakenly targeting innocent people for aggressive law enforcement. M oreover, the interaction of police and citizens to produce a voluntary police intervention incorporated elements of procedural fairness ${ }^{67}-$ including ethical and objective treatment-that promoted trust and confidence in the law and legal actors as well as higher rates of compliance with legal norms. ${ }^{68}$ 


\section{When juveniles lose their guns, will they re-arm? This seems likely if broader steps are not initiated to reduce the overall perceived level of gun-related danger.}

Some obvious questions arise about this "soft approach" 69 to gun-specific search and seizure. First, the level of perceived coerciveness in these situations is unclear. H ow voluntary is "consent" when police officers arrive at the door and ask permission to search the home? Citizen refusals raise a related challenge. If police respond to a refusal by obtaining a warrant and conducting a nonconsensual search, the authenticity of the "consensual" search is compromised.

Second, security and control may not directly increase when neighbors are encouraged to "snitch" on each other. ${ }^{70}$ Police-citizen interactions differ when a parent invites the police to a home, compared to when a citizen refers police to a neighbor's home. The latter situation does little to knit social ties among neighbors and may lead to counterproductive scenarios in which neighbors accuse each other falsely or fail to come to each other's aid when crimes occur nearby.

Other challenges are implicit in the program. The information provided to police is likely to vary in authenticity, from poor (from jailhouse informants or vindictive neighbors) to very good (from parents). The balance of risks is delicate for police. If police act on poor and inaccurate information, they risk negative reaction from families that could undermine later searches. If they reject information, they risk a gun crime that might have been prevented.

Moreover, what rate of seizures per search will be viewed as successful, compared to seizures resulting from more coercive tactics? A low "hit rate" when searches are voluntary may create internal pressure either to increase coercion or to abandon the voluntary component of searches. Finally, when juveniles lose their guns, will they re-arm? This seems likely if broader steps are not initiated to reduce the overall perceived level of gun-related danger. ${ }^{63}$

The comparative advantage of voluntary searches is the promise of citizen-police interaction to reduce gun violence- a partnership that can have secondary benefits for social control of youth crime. Complex opera- tional questions challenge the program, however, and it must operate in tension with police culture; noncriminal justice alternatives work against a norm that rewards police for the arrests they make. ${ }^{71}$ Evidently, neither the program's benefits in crime control nor its internal support were sufficient to sustain it; the program was disbanded in 1998, shortly after a new police chief was named in St. Louis.

\section{Therapeutic J urisprudence for Young Gun Offenders in Detroit}

Another effort to reduce gun violence among youth built on the growing influence of therapeutic jurisprudence, or "treatment courts," in American justice systems. A specialized court in D etroit tried to convince juvenile gun offenders to put down their weapons. An evaluation of the court found that it did change youth attitudes toward guns, but that it led to little corresponding behavioral change- partly because the specialized court did nothing to address dangers in the community that led youth to feel they needed to carry guns for protection. ${ }^{62}$

The typical treatment court works this way: Persons charged with specific offenses consent to have charges filed, then plead guilty or accept responsibility. The defendant then accepts placement in a treatment program in lieu of formal punishment. If progress in the program is deemed satisfactory, charges are dropped or the conviction is expunged; otherwise, the court may choose a different service provider, often more intensive and restrictive, or reinstate formal punishment. The term therapeutic jurisprudence reflects the emphasis in these courts on behavioral change through treatment interventions motivated and monitored within a legal framework. ${ }^{72}$

This approach was applied to youth gun violence in a specialized court in Detroit. ${ }^{62}$ Offenders charged with possession of handguns were required to attend a fourhour class held in the courtroom as a condition of pretrial release. Classes emphasized the dangers of handguns and challenged participants to take personal responsibility for reducing the negative consequences of 


\section{U nfortunately, assessing the effectiveness of police interventions regarding youth gun violence is difficult at best.}

gun possession. The program included dialogues with the judge, focusing on culture and responsibility; slide shows depicting murder victims; interactions with older felons; and a "pledge" not to initiate gun violence. ${ }^{73}$

A randomized trial involving 446 subjects showed significant and positive effects in a two-week follow-up, including (1) weaker belief that guns afforded control in threatening situations, (2) stronger belief that gun fights could be avoided, (3) weaker support for gun use in conflict situations, (4) weaker belief that guns afforded positive social status, (5) stronger belief that ties should be broken with peers who continued to carry or use guns, (6) stronger support to avoid situations where guns might be present, and (7) greater knowledge about the risks of injury and death from gun use. ${ }^{73}$ These attitudinal changes rarely translated into behavioral change, however. In focus groups, many participants said that everyday danger and fear motivated gun possession, gun carrying, and at times, gun use.

Two lessons follow from this limited experience. First, a specialized court for youth gun offenders might be an effective forum to bring about cognitive and attitudinal change. It is steeped in legitimacy, with a judge whose personal involvement imbues the legal interaction with moral authority. M essages that might otherwise be dismissed may be taken seriously in this forum. Second, however, the decisions of young persons to carry weapons reflect their assessments of danger in their lives. Policing and legal sanctions for gun violence may be effective only when young people perceive that a broader shift in norms is reducing the level of danger in their communities and the motivation for gun use that it evokes.

\section{Mental Health Partnerships to Reduce the Trauma of Gun Violence in New Haven}

The lethality of youth gun violence is compounded by traumatic effects on bystanders, peers, and others caught in its ecology of danger. When teens witness or experience violence, or see the aftermath of a violent act they committed, the traumatic effects can adversely affect development and shape how teens react in the future to threatening situations. ${ }^{74}$ (See the article by Garbarino,
Bradshaw, and Vorrasi.) In N ew $\mathrm{H}$ aven, police and mental health officials came together in an innovative collaboration to help children and youth cope with gun-related trauma. The idea was to prevent future youth violence by addressing trauma when it occurs.

Police are hard pressed to deal with trauma, even though they have frequent contact with children involved in shootings. Culturally, most police lack the training to deal with the psychological aftermath of gun violence, and the demands of their job rarely leave time for sustained involvement. Police culture provides little support for reacting therapeutically. In the worst of circumstances, police involvement can aggravate trauma rather than ameliorating it.

The Child Development-Community Policing Program in $\mathrm{New} \mathrm{H}$ aven, located at the Yale U niversity School of Medicine, incorporated principles of child development and psychological functioning into the everyday work of police officers. ${ }^{75}$ It also built institutional linkages between police and mental health, integrated community participation into police planning and supervision, and altered police approaches in encounters with children exposed to violence.

This process built on a strong platform of police-citizen interaction, begun in 1991, that already had credibility and momentum in $\mathrm{New} \mathrm{H}$ aven. Credible relationships with citizens made possible police-citizen interactions focused on problem solving, especially where recurring violence and its traumatic components were concerned.

The Yale U niversity staff sought to shift social norms among the police and mental health professionals by offering fellowships to a 10-week seminar they created for management and line staff from both fields. The seminar was heavily experience-based, with case studies that helped participants build a common language about trauma and adolescence. The program also created a consultation service to help officers who recognized the need for intervention with traumatized children and youth that they encountered. Police officers used their new clinical perspective to interact with 
schools to address truancy problems, and with child welfare workers regarding placements for children removed from their homes because of violence or neglect. The integration of mental health perspectives into police work, and the development of concrete ties between police and mental health systems, had tangible payoffs for police and motivated openness to new ways of approaching problems of youth violence.

\section{Conclusion}

Two critical questions remain about the efforts of the cities described in this article. First, did these policing innovations help reduce youth gun violence? Second, what lessons do these experiences offer for future policing strategy, specifically in the context of adolescent gun violence?

Analyses of gun violence rates in the nation's 20 largest cities suggest few differences from one place to the next in the patterns of gun violence since 1985. ${ }^{37}$ Even in cities such as H ouston and Dallas, where no specific policing innovations took place during this time, gun violence rates rose and fell in roughly the same pattern as in the cities described in this article. It is not only fair but critical to ask, "How much do police make a difference?"

U nfortunately, assessing the effectiveness of police interventions regarding youth gun violence is difficult at best. Efforts to understand how policy affects gun violence will need to disentangle the competing and overlapping effects of police interventions. M easures to capture "dosages" of enforcement and social control under different rubrics need to be developed. The role of larger forces-such as the business cycle, large-scale nationwide demographic shifts, declining drug markets, and rising rates of incarceration-must also be considered seriously. ${ }^{76}$

These case studies do suggest that policing alone cannot contain lethal youth violence. The challenge to policing, then, is to contain the epidemic nature of gun violence while promoting social control and regulation to resist future waves of gun violence. Police actions are not likely to stop the cycle of youth gun violence, but their tactics can shape the history of that violence: how long it persists, how serious it is at its peak, and whether its aftermath hastens or forestalls future epidemics. Strategies that balance security, social control, and legitimacy are essential to shift norms on a scale that matches the prevalence of lethal youth violence.

The case studies also show the importance of focusing police strategies on guns and gun violence, not just on people. Police must incorporate procedural justice and moral legitimacy in order to make their efforts salient among youth and adults in communities burdened with gun violence and promote the citizen-police interactions that will produce security.

It is also crucial to recognize two specific contexts surrounding youth gun violence that require thoughtful approaches: adolescent development and the role of race. First, youth gun violence reflects a crisis of adolescent development in contexts of violence and danger. ${ }^{77}$ The complex role that gun violence plays in the formation of social identity, and the behavioral scripts that teens use to negotiate the challenges of everyday life, must be considered in the design of strategies for controlling gun violence.

Second, race is everywhere in this equation and must be a factor in policing. Communities that suffer loss and injury from gun violence are most often those that are racially segregated and socially disadvantaged. Policing in this social context requires sensitivity to questions of legitimacy and procedural fairness. When policing is perceived as externally imposed, casting a broad net of guilt, and performed with little consent of the citizens most affected, each interaction between police and citizens can corrode the legitimacy of the law and police. Each interaction also can motivate or deter citizens from participating in the tasks of social control. Reconfiguring criminal justice along lines of legitimacy and proportional and procedural fairness will benefit youth and adults alike and broaden the web of social control to reduce the danger that guns pose to children and youth in the $U$ nited States. 


\section{ENDNOTES}

1. Legislators toughened laws for crimes committed with firearms, many of which targeted adolescents. N early every state has changed its laws since 1990 to permit more certain and harsher punishment of violent juvenile offenders in the criminal justice system. See Torbet, P., Gable, R., H urst, H ., et al. State responses to serious and violent juvenile crime. Research report. Washington, DC: O ffice of J uvenile J ustice and D elinquency Prevention, 1996; Feld, B.C. Bad kids N ew York: O xford U niversity Press, 1998; Zimring, F.E. A merican youth violence. N ew York: Oxford U niversity Press, 1998; and Fagan, J., and Zimring, F.E., eds. Changing borders of juvenilejustice: Transfer of adolescents to the criminal court. Chicago: U niversity of Chicago Press, 2000.

2. Goldstein, H. Problem-oriented policing. Philadelphia, PA: Temple U niversity Press, 1990; Greene, J.R., and M astrofski, S.D., eds. Community policing: R hetoric or reality? N ew York: Praeger, 1988; and Skolnick, J.D., and Bayley, D. The new blue line: Police innovation in sx A merican cities N ew York: Free Press, 1986.

3. For a detailed analysis of the conceptual bases of these innovations and a description of them in practice, see Livingston, D. Police discretion and the quality of life in public places: Courts, communities, and the new policing. Columbia Law R eview (1997) 97(3):551-672.

4. Wilson, J.Q., and Kelling, G.L. The police and neighborhood safety: Broken windows. A tlantic M onthly (1982) 249(3):29-38.

5. Kennedy, D.M. Guns and violence: Pulling levers: Chronic offenders, high-crime settings, and a theory of prevention. Valparaiso Law R eview (1997) 31(2):449-80.

6. See note no. 2, Goldstein; Skogan, W., and H artnett, S.M. Community policing, Chicago syle N ew York: O xford U niversity Press, 1997; and Greene, J.R., and Taylor, R.B. Community-based policing and foot patrol: Issues of theory and evaluation. In Community policing: R hetoric or reality? J.R. Greene and S.D. M astrofski, eds. N ew York: Praeger, 1988.

7. Some of these experiments took place in the context of multiple law enforcement interventions, complicating the attribution of change to specific strategies.

8. Greene, J.A. Zero tolerance: A case study of police policies and practices in N ew York City. Crime and D elinquency (1999) 45(2):171-87.

9. Personal communication with former San D iego Police Chief J erry Sanders, N ovember 2001.

10. Kennedy, D.M. Pulling levers: Getting deterrence right. N ational Institute of J ustice J ournal (J une 1998) 2(36):238-49.

11. Winship, C., and Berrien, J. Boston cops and black churches. Public Interest (Summer 1999) 136:52-68.

12. Scandals included a pattern of unconstitutional "stop-and-frisk" drug interventions and the sweeps of African American males as suspects in the wake of a racial hoax alleging the murder of a white woman, Carol Stuart, by an African American male. These sweeps led to the arrest of an African American suspect, William Bennett, who was ultimately exonerated when suspicion shifted to Charles Stuart, Carol Stuart's husband. Charles Stuart eventually committed suicide. See H eymann, P.B. The new policing. Fordham U rban Law J ournal (2000) 28(2):407-56. See also, M assachusetts Attorney General's 0 ffice. R eport of the A ttorney General's Civil Rights Division on Boston Police
Department practices Boston, M A: O ffice of the State Attorney General, D ecember 18, 1990.

13. Reardon, C. Faith matters: A ministry for the mean streets. Ford Foundation R eport (Spring/ Summer 1999) 30:8-10.

14. See note no. 12, H eymann.

15. Stoutland, S. Trust, police legitimacy, and efforts to reduce youth violent crime: Community perspectives from Boston. U npublished manuscript. Cambridge, M A: J ohn F. Kennedy School of Government, $\mathrm{H}$ arvard U niversity.

16. Tyler, T.R., and D arley, J.M. Building a law-abiding society: Taking public views about morality and the legitimacy of legal authorities into account when formulating substantive criminal law. $\mathrm{H}$ ofstra Law R eview (2000) 28(3):707-39 (showing the interaction between procedural fairness, perceptions of legitimacy, and willingness to comply with the moral and normative bases of law).

17. Fung, A. Street level democracy: A theory of popular pragmatic deliberation and its practice in Chicago school governance and community policing, 1988-97. Ph.D. diss., M assachusetts I nstitute of Technology, 1999.

18. Chicago Community Policing Evaluation Consortium. Community policing in Chicago. Interim report. Evanston, IL: Institute for Policy Research, N orthwestern U niversity, 1994.

19. See note no. 17, Fung, citing various annual reports of the Chicago Community Policing Evaluation Forum.

20. Fung, A. D eliberative democracy, Chicago style. Paper presented at the Conference on Real U topias V: Experiments in Empowered D eliberative D emocracy. M adison, WI. January 2000.

21. See note no. 6 , Skogan and $H$ artnett.

22. Skogan, W., H artnett, S., D uBois, J., et al. On the beat: Police and community problem solving in $\mathrm{C}$ hicago. Boulder, $\mathrm{CO}$ : Westview Press, 1999.

23. See note no. 12, H eymann.

24. The ordinance stated, "Whenever a police officer observes a person whom he reasonably believes to be a criminal street gang member loitering in any public place with one or more other persons, he shall order all such persons to disperse and remove themselves from the area. Any person who does not promptly obey such an order is in violation of this section...'C riminal street gang' means any ongoing organization, association in fact or group of three or more persons, whether formal or informal, having as one of its substantial activities the commission of one or more of the criminal acts enumerated in paragraph (3), and whose members individually or collectively engage in or have engaged in a pattern of criminal gang activity." Chicago M unicipal Code §8-4-015 (J une 17, 1992). Each violation of the ordinance is punishable by a fine of up to $\$ 500$, imprisonment for not more than six months, and up to 120 hours of community service.

25. The Chicago Police D epartment's General O rder 92-4 limited officers' enforcement discretion by (1) confining arrest authority to designated officers, (2) establishing detailed criteria for defining street gangs and membership therein, and (3) providing for designated but publicly undisclosed enforcement areas. See M eares, T.L., and Kahan, D. Brief amicus curiae of the C hicago neighborhood organizations in support of petitioner, City of C hicago $\mathrm{V}$. 
Morales, 119 S. Ct. 1849 (1999) (no. 97-1121). A vailable online at LEXIS, Supreme Court Cases and M aterials Library, U.S. Supreme Court Briefs File; see also M eares, T.L., and Kahan, D. Foreword: The coming crisis of criminal procedure. Georgetown Law J ournal (1998) 86(5):1153-84.

26. City of Chicago v. Morales, 119 S. Ct. 1849 (1999).

27. H arcourt, B.E. After the "Social M eaning Turn": Implication for research design and methods of proof in contemporary criminal law policy analysis. Law \& Society R eview (1998) 34(1):179-211.

28. Schulhofer, S.J. Inner city policing after City of Chicago v. M orales. Paper presented at the Fortunoff Colloquium, N ew York U niversity School of Law. N ew York, NY: J anuary 25, 2000.

29. See note no. 25, M eares and Kahan, 1999.

30. Grossman, H ., Lipson, M., Schwartz, A.D., and O 'Toole, B. Brief of respondents, City of Chicago v. M orales, $119 \mathrm{~S}$. Ct. 1849 (1999) (no. 97-1121). Available online at LEXIS, Supreme Court Cases and M aterials Library, U.S. Supreme Court Briefs File.

31. Fagan, J., and M eares, T.L. Punishment, deterrence and social control: The paradox of punishment in minority communities. Punishment \& Society, in press. Also available online at http:/ / papers2.ssrn.com/ papers.taf?abstract_id=223148; and Tyler, T.R Public trust and confidence in legal authorities: What do people want from the law and legal institutions? Behavioral Science and the Law (2001) 19(2):215-35. N eighborhood residents in high crime neighborhood often express satisfaction with the lowered crime rate, but greater distrust of police when aggressive stop, search, and arrest tactics are used. Tyler also notes that some judgments are made on vicarious experiences of neighbors and friends.

32. Fernkoff, E. H illard vows new blitz to cut murders. Chicago Tribune January 18, 2002, at 1; and Fernkoff, E. Local gun cases going federal. Chicago Tribune. M ay 7, 2002, at 1 . Cook County and the counties surrounding Chicago will become part of a $\$ 532$ million federal program to prosecute gun crimes in federal courts, where sentences are typically far harsher than in state courts. Bringing this program to Chicago was a reaction to Chicago's sharp spike in homicides in 2001. It is modeled closely after Project Exile, which is discussed later in this journal article.

33. See note no. 4, Wilson and Kelling, p. 31. For reviews of Broken Windows theory, see note no. 3, Livingston, p. 578 (discussing the relationship between Broken Windows theory and current policing practices); $\mathrm{H}$ arcourt, B.E. Reflecting on the subject: A critique of the social influence conception of deterrence, the Broken Windows theory, and O rder-M aintenance Policing $\mathrm{N}$ ew York style. Michigan Law R eview (1998) 97(2):291-356 (critiquing Broken Windows theory and empirical research claiming to support the link between disorder and crime); and M eares, T.L., and Kahan, D.M . Law and (norms of) order in the inner city. Law and Society R eview (1998) 32(4):805-31 (discussing the link between social norms theory and law enforcement policies).

34. See note no. 3, Livingston, p. 632.

35. D efinitions of the crimes that constitute disorder vary but generally include unlicensed peddling and vending, public drunkenness and open drinking, vandalism (including graffiti), public urination, loitering, littering, panhandling, prostitution, and menacing misbehavior. The latter often is symbolized by "squeegee" men who solicit money in return for unsolicited cleaning of motorists' wind- shields at stoplights, the type of activity subject to O M P enforcement that most closely expressed popular conceptions of the policy. See Kelling, G., and Coles, C. Fixing broken windows N ew York: Free Press, 1996. M ore recently, O M P was extended to control jaywalking and unleashed dogs. See Waldeck, S.E. Cops, community policing, and the social norms approach to crime control: Should one make us more comfortable with the others? Georgia Law R eview (2000) 34(3):1253-1310; Bratton, W., and Knobler, P. Turnaround: H ow A merica's top cop reversed the crime epidemic. N ew York: Random H ouse, 1998 (discussing the NYPD's policy to rid the city of squeegee people); and Bratton, W.J. The N ew York City Police D epartment's civil enforcement of quality-of-life crimes. Journal of Law and Policy (1995) 3(3):447-64.

36. See, for example, note no. 3, Livingston, p. 584; note no. 2, Goldstein, p. 134; Kelling, G.L., and M oore, M.H. From political to reform to community: The evolving strategy of police. In Community policing: R hetoric or reality? J.R. Greene and S.D. M astrofski, eds. N ew York: Praeger, 1988; and M astrofski, S.D. Community policing as reform: A cautionary tale. In Community policing: R hetoric or reality? N ew York: Praeger, 1988.

37. Fagan, J., Zimring, F., and Kim, J. Declining homicide in $\mathrm{N}$ ew York: A tale of two trends. Journal of Criminal Law and Criminology (1998) 88(4):1277-1324.

38. Fagan, J., and D avies, G.D. Street stops and broken windows: Terry, race, and disorder in $\mathrm{N}$ ew York City. Fordham U rban Law Journal (2000) 28(2):456-503.

39. These tactical shifts were intended to raise the stakes for criminals who carried guns. The policy assumed, quite explicitly, that the fact that would-be offenders were more likely to be stopped for minor crimes or infractions would deter them from carrying guns. See note no. 35, Bratton and Knobler, pp. 219-20; Silverman, E. N Y PD battles crime: I nnovative strategies in policing. Boston: N ortheastern U niversity Press, 1999; and Karmen, A. $\mathrm{N}$ ew York murder mystery: The true story behind the crime crash of the 1990s. N ew York: N ew York U niversity Press, 2000.

40. See note no. 6, Skogan and $\mathrm{H}$ artnett; and note no. 2, Goldstein.

41. See note no. 35 , Kelling and Coles.

42. See note no. 35 , Waldeck.

43. Skogan, W.G. Disorder and decline: Crime and the spiral of decay in A merican neighborhoods. N ew York: Free Press, 1990; and Sampson, R.J., and Raudenbush, S.W. Systematic social observation of public spaces: A new look at disorder in urban neighborhoods. A merican Journal of Sociology (1999) 105(3):603-51.

44. Kocieniewski, D. Success of elite police unit exacts a toll on the streets. N ew York Times. February 15, 1999, at A1 (discussing reactions of citizens to aggressive policing in $\mathrm{N}$ ew York City); and Roane, K.R. M inority private-school students claim police harassment. $\mathrm{N}$ ew York Times. M arch 26, 1999, at B5 (citing complaints by minority students of indiscriminate and frequent police harassment).

45. There is an irony about the use of such citizen detentions and searches as a crime-fighting tool. The decision in Terry v. Ohio, 392 U .S. 1 (1968), identified the frisk less as an investigative aid than as a protection for the patrolling officer: "The frisk...was essential to the proper performance of the officer's investigatory duties, for without it the answer to the police officer may be a bullet." That 
stop-and-frisk tactics engender animosity was made explicit in the original Terry decision. The Supreme Court in Terry noted that a frisk "is a serious intrusion upon the sanctity of the person, which may inflict great indignity and arouse strong resentment, and is not to be undertaken lightly" (392 U .S., at 17, 88 S. Ct. 1868). The Court also noted that Terry stops had the potential to inflict psychological harm: "Even a limited search constitutes a severe, though brief, intrusion upon cherished personal security, and it must be an annoying, frightening, and perhaps humiliating experience."

46. See, for example, Fish, J.F. Is our drug policy effective? Are there alternatives? Fordham U rban Law J ournal (2000) 28(1):9-21.

47. Citizens who are stopped and frisked based on a profiling or racial policing strategy often know that they have been singled out because of their race. These encounters have been termed "race-making situations." See Jones, D.R. The racial ghetto as a race-making situation: The effects of residential segregation on racial inequalities and racial identity. Law and Social Inquiry (1994) 19(2):407-32. The outrage of many minority citizens to the NYPD's policy of aggressive stops and frisks reflects not only the emotional harm from being targeted because of one's race, but also the fear that such situations can escalate into dangerously violent encounters. See $\mathrm{H}$ arris, D.A. The stories, the statistics, and the law: Why "driving while black" matters. Minnesota Law R eview (1999) 84(2):265-326. The shared danger of profiling encounters reflects the concept of "linked fate" among residents of minority neighborhoods. "Linked fate" refers to the empathy that people have with family and friends. It can also exist among strangers. In the African American community, "linked fate" has its foundation in the fact that race has historically shaped the life chances of African Americans. Linked fate explains that when race overdetermines an individual's life chances, it is much more efficient for that individual to use the relative and absolute status of the group as a proxy for individual utility. See Dawson, M .C. Behind the mule: $R$ ace and class in A frican-A merican politics Princeton, N J: Princeton U niversity Press, 1994.

48. O ffice of the Attorney General of the State of N ew York, Civil Rights Bureau. The N ew York City Police D epartment's "stop and frisk" practices N ew York: O ffice of the Attorney General, December 1999; also see note no. 44, Kocieniewski.

49. See note no. 37, Fagan, et al. (crediting the decline in gun violence in part to "gun-oriented policing"); and note no. 35 , Waldeck, pp. 1283-84 (suggesting that the stop-and-frisk tactics produced a crackdown that deterred many from carrying weapons or drugs).

50. See note no. 33, $\mathrm{H}$ arcourt, p. 342.

51. Richman, D.C. Project Exile and the allocation of federal law enforcement authority. A rizona Law R eview (2001) 43(2):369-411.

52. U nited States Attorney's O ffice for the Eastern District of Virginia, Richmond Division. Project Exile (M arch 22, 1999) 3.

53. See note no. 51, Richman, at notes $9-14$ and accompanying text.

54. Campbell, T. Gun users to face rigors of U .S. case: 59 are indicted in local-federal effort. Richmond Times D ispatch. M arch 7, 1997, at B5.

55. Campbell, T. An "exile" for firearms? Some gun-toting criminals face federal prosecution. Richmond Times Dispatch. July 7, 1997, at A1.

56. Janofsky, M. Fighting crime by making a federal case about guns. $\mathrm{N}$ ew York Times. February 10, 1999, at A12.

57. Raphael, S., and Ludwig, J. D o prison sentence enhancements reduce gun crime? The case of Project Exile. Paper presented at the Brookings Conference on Gun Violence and Gun Policy. Washington, DC. January 24-25, 2002.

58. M yers, J. O peration Safe N eighborhoods: D eterring gun violence in Baltimore. Paper presented at RAN D C riminal Justice Workshop on Effective Strategies to Reduce Gun Violence. Santa M onica, CA. January 21, 2000.

59. See note no. 58, M yers, p. 4.

60. Scales, B., and Baker, J. Seattle's effective strategy for prosecuting juvenile firearm offenders (NCJ 178901). U.S. Department of Justice, O ffice of J uvenile J ustice and D elinquency Prevention (M arch 2000).

61. See note no. 60, Scales and Baker, p. 6.

62. Roth, J.A. The D etroit $\mathrm{H}$ andgun Intervention Program: A court-based program for youthful handgun offenders (NCJ FS 000231). N ational Institute of J ustice R esearch Preview. Washington, DC: NIJ, N ovember 1998.

63. Fagan, J., and Wilkinson, D.L. Guns, youth violence and social identity in inner cities. In Youth violence, Vol. 24, Crime and jus tice: A review of research. M. Tonry and M.H. M oore, eds. Chicago: U niversity of Chicago Press, 1998, pp. 105-88.

64. Rosenfeld, R., and D ecker, S.H . Consent to search and seize: Evaluating an innovative youth firearm suppression program. Law and Contemporary Problems (Winter 1996) 59(1):197-224.

65. A similar program has been developed in Tucson, Arizona. As part of Project Excaliber, Tucson Police D epartment officers conduct "knock-and-talk" consensual searches. O fficers knock on the door of a residence where they suspect that illegal guns are present and ask permission to search the home for guns. See Gun violence reduction plan (Project Excaliber). M ayor and Council M emorandum. Tucson, AZ, D ecember 18, 2000, p. 9.

66. See note no. 64, Rosenfeld and Decker, p. 204.

67. See note no. 64, Rosenfeld and D ecker, p. 204, citing anecdotes describing broad acceptance of police interventions by consenting citizens.

68. Tyler, T.R. Why people obey the law. N ew H aven, CT: Yale U niversity Press, 1990.

69. Bryan, B. Soft sell of searches nets police 3,900 guns. St. Louis Post-D ispatch. A pril 10, 1995, at 13A.

70. Some argue, however, that snitching may build social norms by promoting constructive interactions between police and citizens to align police authority with citizens who wish to combat antisocial norms and activities but are intimidated from exerting social regulation directly. See note no. 33, M eares and Kahan.

71. See note no. 35, Waldeck.

72. D rug treatment courts are the best-known example of therapeutic jurisprudence. Juvenile courts are the early models for specialized courts, and some have risen to the status of therapeutic 
jurisprudence. D omestic violence courts, courts specializing in cases involving mentally ill offenders, and courts for prostitutes and others engaged in recurring crimes also practice therapeutic jurisprudence. Their involvement in the complex behavioral dynamics and systemic problems that produce crime set them apart from courts whose jurisprudence is organized around regimes of rights and punishments. See D orf, M.C., and Sabel, C.F. D rug treatment courts and emergent experimentalist government. Vanderbilt Law R eview (2000) 53(3):831-83; H ora, P.F., Schma, W.G., and Rosenthal, J.T.A. Therapeutic jurisprudence and the drug court movement: Revolutionizing the criminal justice system's response to drug abuse and crime in America. N otre D ame Law R eview (1999) 74(2):439-537; Rottman, D., and Casey, P. Therapeutic jurisprudence and the emergence of problem-solving courts. $\mathrm{N}$ ational Institute of J ustice J ournal (July 1999) 240:12-19; and Wexler, D.B., and Winick, B.J. Law in a therapeutic key: D evelopments in therapeutic jurisprudence Chapel H ill, N C: Carolina Academic Press, 1996.
73. See note no. 62 , Roth, p. 2

74. Richters, J., and M artinez, P. The N I M H community violence project: I. Children as victims of and witnesses to violence. Psychiatry (1993) 56(1):7-21.

75. M arans, S., and Berkman, M. Child development-community policing: A partnership in a climate of violence (NCJ 164380). Washington, D C: U .S. D epartment of J ustice, O ffice of J uvenile Justice and D elinquency Prevention, M arch 1997; and M arans, S. The police-mental health partnership: A community-based response to urban violence. N ew H aven, CT: Yale U niversity Press, 1995.

76. Blumstein, A., and Wallman, J., eds. The crime drop in A merica. N ew York: Cambridge U niversity Press, 2000; and LaFree, G. Losing legitimacy. Boulder, CO : Westview Press, 1998.

77. Fagan, J., and Wilkinson, D.L. The social contexts and developmental functions of adolescent violence. In Violence in A merican schools. D.S. Elliott, B.A. H amburg, and K.R. Williams, eds. N ew York: Cambridge U niversity Press, 1998. 